\title{
Forecasting Stock Price PT. Telkom Using Hybrid Time Series Regression Linear-Autoregressive Integrated Moving Average Model
}

\section{Peramalan Harga Saham PT. Telkom Menggunakan Model Hybrid Time Series Regression linier - Autoregressive Integrated Moving Average}

\author{
Kartika Ramadani $^{* 1}$, Sri Wahyuningsih ${ }^{* 2}$, Memi Nor Hayati ${ }^{* 3}$
}

\begin{abstract}
The hybrid method is a method of combining two forecasting models. Hybrid method is used to improve forecasting accuracy. In this study, the Time Series Regression (TSR) linear model will be combined with the Autoregressive Integrated Moving Average (ARIMA) model. The TSR linear model is used to obtain the model and residual value, then the residual value of the TSR linear model will be modeled by the ARIMA model. This combination method will produce a hybrid TSR linear-ARIMA model. The case study in this research is stock closing price (daily) of PT. Telkom Indonesia Tbk. The stock closing price (daily) of PT. Telkom Indonesia Tbk in 2020 showed an decreasing and increasing trend pattern. The results of this study, obtained the best model of hybrid TSR linear-ARIMA $(2,1,1)$ with the proportion of data training and testing is 70:30. In the best model, the MAD value is 56.595, the MAPE value is $1.880 \%$, and the RMSE value is 78.663. It is also found that the hybrid TSR linear-ARIMA model has a smaller error value than the TSR linear model. The results of forecasting the stock price of PT. Telkom Indonesia Tbk for the period 02 January 2021 to 29 January 2021 formed a decreasing trend pattern.
\end{abstract}

Keywords: Forecasting, hybrid TSR linear-ARIMA, Stock price, trend.

\begin{abstract}
Abstrak
Metode hybrid merupakan metode penggabungan dua model peramalan. Metode hybrid digunakana untuk meningkatkan akurasi peramalan.Pada penelitian ini, model Time Series Regression (TSR) linier akan digabungkan dengan model Autoregressive Integrated Moving Average (ARIMA). Model TSR linier digunakan untuk memperoleh model dan nilai residual, kemudian nilai residual dari model TSR linier akan dimodelkan oleh model ARIMA. Metode penggabungan ini akan menghasilkan model hybrid TSR linier-ARIMA. Studi kasus dalam penelitian ini adalah harga penutupan saham (harian) PT. Telkom Indonesia Tbk. Harga penutupan saham (harian) PT. Telkom Indonesia Tbk pada tahun 2020 menunjukkan pola trend turun dan trend naik. Hasil penelitian ini, diperoleh model terbaik hybrid TSR linier-ARIMA $(2,1,1)$ dengan proporsi data training dan testing adalah 70:30. Pada model terbaik, diperoleh nilai MAD sebesar 56,595, nilai MAPE sebesar 1,880\%, dan nilai RMSE sebesar 78,663. Model hybrid TSR linier-ARIMA memiliki nilai kesalahan yang lebih kecil dibandingkan dengan model TSR linier. Hasil peramalan harga saham PT. Telkom Indonesia Tbk periode 02 Januari 2021 sampai dengan 29 Januari 2021 membentuk pola trend turun.
\end{abstract}

Kata kunci: Harga saham, hybrid TSR linier-ARIMA, peramalan, trend.

"Program Studi S1 Statistika, Fakultas MIPA, Universitas Mulawarman

Email address: kartikaramadani37@gmail.com ${ }^{1}$,swahyuningsih@fmipa.unmul.ac.id ${ }^{2}$, meminorhayati@fmipa.unmul.ac.id

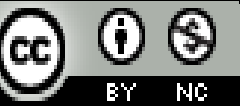




\section{Jumal Matematika, Statistika \& Komputasi Kartika Ramadani, Sri Wahyuningsih, Memi Nor Hayati}

\section{PENDAHULUAN}

\subsection{Latar Belakang}

TSR linier merupakan model peramalan yang menggunakan variabel dependen dan variabel independen dalam pemodelan. Variabel dependen maupun variabel independen sama-sama merupakan runtun waktu dengan asumsi variabel independen mempengaruhi variabel dependen. Model TSR linier dapat digunakan pada data yang memiliki pola trend maupun seasonal [2].

Model ARIMA adalah model peramalan yang tidak mensyaratkan suatu pola data tertentu. Hal ini berarti model ARIMA dapat digunakan untuk semua tipe pola data, baik pola data stasioner maupun tidak stasioner. Pola data yang tidak stasioner akan distasionerkan pada saat proses pembentukan model. Model ARIMA hanya menggunakan variabel dependen sebagai dasar acuan dalam meramalkan [9].

Penggunaan model ARIMA ataupun TSR dalam peramalan terkadang memiliki nilai kesalahan yang relatif besar atau nilai akurasi yang rendah. Akurasi dalam meramalkan sangat menentukan baik tidaknya suatu ramalan, sehingga keakuratan ramalan menjadi sangat penting. Namun, seakurat apapun sebuah peramalan selalu ada unsur kesalahan, maka yang perlu diperhatikan adalah memperkecil kesalahan atau meningkatkan akurasi hasil peramalan [5].

Secara umum, terdapat dua cara yang sering dilakukan oleh peneliti dalam meningkatkan akurasi peramalan, yaitu mengembangkan atau mengusulkan model peramalan baru dan model hybrid atau menggabungkan antara dua atau lebih model peramalan. Pemodelan hybrid umumnya dilakukan karena kurangnya model individu yang komprehensif dalam menangkap berbagai pola dalam data secara bersamaan [5].

Peran peramalan dibutuhkan dalam bidang investasi saham. Bagi investor, peramalan harga saham menjadi salah satu hal penting dalam pengambilan keputusan berinvestasi. Pemodelan dan peramalan harga saham yang akurat diperlukan sebagai dasar dalam pengambilan keputusan investasi. Salah satu perusahaan milik BUMN yang memperdagangkan sahamnya adalah PT. Telkom Indonesia Tbk. Pemegang saham mayoritas PT. Telkom Indonesia Tbk adalah Pemerintah Republik Indonesia sebesar 52.09\%, sedangkan $47.91 \%$ sisanya dikuasai oleh publik [12]. Harga penutupan saham PT. Telkom Indonesia Tbk pada tahun 2020 menunjukkan pola trend turun pada bulan Januari sampai dengan Oktober, sedangkan pada bulan November sampai dengan Desember cenderung trend naik.

Berdasarkan latar belakang yang telah diuraikan, penulis tertarik untuk memodelkan dan meramalkan harga penutupan saham PT. Telkom Indonesia Tbk menggunakan model hybrid TSR linier-ARIMA. Kemudian memperoleh pola peramalan harga saham dan memperoleh nilai kesalahan model peramalan.

\subsection{Peramalan}

Peramalan adalah perkiraan yang akan terjadi pada waktu yang akan datang [14]. Metode peramalan dapat dibagi menjadi dua kategori, yaitu metode kualitatif dan metode kuantitatif. Terdapat dua model peramalan kuantitatif, yaitu model runtun waktu (time series) dan model regresi (regression) [1]. Runtun waktu merupakan kumpulan pengamatan yang diambil secara berurutan dari waktu ke waktu. Model runtun waktu dibuat karena terdapat hubungan atau korelasi antar deret pengamatan [10].

\subsection{Model Time Series Regression (TSR)}

Model TSR mempunyai bentuk model yang sama dengan regresi pada umumnya. Namun, terdapat perbedaan diantara keduanya, yaitu pada TSR variabel dependen dan variabel independennya merupakan runtun waktu. Model regresi linier sederhana dapat dituliskan sebagai berikut [2]:

$$
Y=\beta_{0}+\beta_{1} x+e,
$$

sedangkan model TSR dapat dituliskan sebagai berikut [2]: 


\section{Jumal Matematika, Statistika \& Komputasi}

Kartika Ramadani, Sri Wahyuningsih, Memi Nor Hayati

$$
\begin{gathered}
Y_{t}=T_{t}+S_{t}+e_{t} \\
Y_{t}=\beta_{0}+\beta_{1} t+\beta_{s 1} d_{s 1, t}+\beta_{s 2} d_{s 2, t}+\ldots+\beta_{s(M-1)} d_{s(M-1), t}+e_{t},
\end{gathered}
$$

dengan $Y_{t}$ adalah variabel dependen atau data pengamatan model TSR periode ke- $t, T_{t}$ adalah komponen trend, $S_{t}$ adalah komponen seasonal, dan $e_{t}$ adalah residual periode ke- $t$. Jika data pengamatan hanya mengandung trend linier, maka Persamaan (1.2) dapat dituliskan sebagai berikut [2]:

$$
\begin{aligned}
& Y_{t}=T_{t}+e_{t} \\
& Y_{t}=\beta_{0}+\beta_{1} t+e_{t},
\end{aligned}
$$

dengan $\beta_{0}$ adalah parameter constant, $\beta_{1}$ adalah parameter periode waktu $t$.

\subsection{Estimasi Parameter Model TSR Linier}

Estimasi parameter menggunakan metode Ordinary Least Square (OLS). Estimasi parameter $\beta_{0}$ dan $\beta_{1}$ dapat diperoleh dengan persamaan berikut [13]:

$$
\begin{aligned}
& \hat{\beta}_{0}=\bar{Y}-\hat{\beta}_{1} \bar{t} \\
& \hat{\beta}_{1}=\frac{\sum_{t=1}^{n} t Y_{t}-\frac{1}{n} \sum_{t=1}^{n} t \sum_{t=1}^{n} Y_{t}}{\left(\sum_{t=1}^{n} t^{2}-\frac{1}{n}\left(\sum_{t=1}^{n} t\right)^{2}\right)}=\frac{\sum_{t=1}^{n} t Y_{t}-n \bar{t} \bar{Y}}{\sum_{t=1}^{n} t^{2}-n \bar{t}^{2}} .
\end{aligned}
$$

\subsection{Model Autoregressive Integrated Moving Average (ARIMA)}

Model ARIMA dapat ditulis dengan notasi ARIMA $(p, d, q)$, di mana $p$ menyatakan orde dari proses AR, $d$ menyatakan orde dari proses differencing, dan $q$ menyatakan orde dari proses MA. Dalam menentukan model ARIMA $(p, d, q)$, dapat dengan menggunakan prosedur Box-Jenkins. Tahapan-tahapan dalam membentuk model ARIMA dimulai dengan mengidentifikasi model, menentukan estimasi parameter, pemeriksaan diagnostik model, dan peramalan.

\section{Identifikasi Model}

Identifikasi model untuk mengecek kestasioneran data terbagi menjadi dua, yaitu stasioner dalam variansi dan stasioner dalam rata-rata. Apabila data tidak stasioner dalam variansi, maka dapat diatasi dengan melakukan transformasi Box-Cox berikut [3]:

$$
Z_{t}^{\lambda}=\left\{\begin{array}{l}
\frac{Z_{t}^{\lambda}-1}{\lambda}, \lambda \neq 0 \\
\ln \left(Z_{t}\right), \lambda=0
\end{array} .\right.
$$

Jika data belum stasioner dalam rata-rata, maka dapat diatasi dengan melakukan differencing. Secara umum proses differencing pada orde ke- $d$ dapat dinyatakan sebagai berikut [15]:

$$
\nabla^{d} Z_{t}=(1-B)^{d} Z_{t}
$$

Kemudian mengidentifikasi model menggunakan plot Autocorrelation function (ACF) dan Partial Autocorrelation Function (PACF) untuk menentukan orde $p$ dan $q$ pada model ARIMA. Adapun model ARIMA secara umum sebagai berikut [7]:

$$
\nabla^{d} Z_{t}=\phi_{1} \nabla^{d} Z_{t-1}+\phi_{2} \nabla^{d} Z_{t-2}+\ldots+\phi_{p} \nabla^{d} Z_{t-p}+a_{t}+\theta_{1} a_{t-1}+\theta_{2} a_{t-2}+\ldots+\theta_{q} a_{t-q}
$$

\section{Estimasi Parameter}

Estimasi parameter menggunakan metode maximum likelihood (ML). Misal diterapkan pada model AR (1), maka diperoleh estimasi parameter model AR (1) berikut [8]: 


\section{Jumal Matematika, Statistika \& Komputasi}

Kartika Ramadani, Sri Wahyuningsih, Memi Nor Hayati

$$
\hat{\phi}_{1}=\frac{\sum_{t=2}^{n} z_{t-1} z_{t}}{\sum_{t=2}^{n} z_{t-1}^{2}} .
$$

Kemudian melakukan pengujian signifikansi parameter model menggunakan uji t [2].

\section{Pemeriksaan Diagnostik}

Pemeriksaan diagnostik terdiri dari dua pemeriksaan, yaitu residual bersifat white noise dan residual berdistribusi normal. Pemeriksaan residual bersifat white noise menggunakan uji Ljung-Box [15] dan pemeriksaan residual berdistribusi normal menggunakan uji KolmogorovSmirnov. Statistik uji yang digunakan pada uji Kolmogorov-smirnov adalah sebagai berikut [4]:

$$
D=\operatorname{Sup}\left|F\left(a_{t}\right)-F_{0}\left(a_{t}\right)\right|
$$

dengan $\operatorname{Sup}\left|F\left(a_{t}\right)-F_{0}\left(a_{t}\right)\right|$ adalah nilai supremum dari $\left|F\left(a_{t}\right)-F_{0}\left(a_{t}\right)\right|, \quad F\left(a_{t}\right)$ adalah fungsi peluang kumulatif yang dihitung dari data sampel, dan $F_{0}\left(a_{t}\right)$ adalah fungsi peluang kumulatif distribusi normal.

\subsection{Model Hybrid TSR linier-ARIMA}

Model hybrid TSR linier-ARIMA adalah gabungan model TSR dan model ARIMA. Penggabungan model dilakukan dengan cara memodelkan data menggunakan model TSR linier, selanjutnya residual dari model TSR linier dimodelkan oleh model ARIMA, kemudian hasil peramalan dari kedua model ditambahkan. Bentuk model hybrid TSR linier-ARIMA $\left(H_{t}\right)$ adalah sebagai berikut [16]:

$$
H_{t}=Y_{t}+Z_{t},
$$

dan diperoleh model peramalan hybrid sebagai berikut [6]:

$$
\hat{H}_{t}=\hat{Y}_{t}+\hat{Z}_{t} \text {, }
$$

dengan $\hat{Y}_{t}$ merupakan peramalan model TSR linier dan $\hat{Z}_{t}$ merupakan peramalan model ARIMA.

\subsection{Kriteria Model Terbaik}

Kriteria model terbaik merupakan model yang mempunyai nilai kesalahan hasil peramalan terkecil. Pemilihan model terbaik berdasarkan data testing dengan pengukuran nilai kesalahan hasil peramalan adalah Mean Absolute Deviation (MAD), Mean Absolute Percentage Error (MAPE), dan Root Mean Square Error (RMSE). Berikut adalah persamaan untuk menghitung MAD [11].

$$
M A D=\frac{1}{L} \sum_{l=1}^{L}\left|Y_{n+l}-\hat{Y}_{n}(l)\right|,
$$

dengan $n$ banyaknya pengamatan data training, $L$ adalah banyaknya pengamatan data testing, dan $l=1,2,3, \ldots, L$. Selanjutnya untuk menghitung MAPE sebagai berikut [15]:

$$
M A P E=\frac{1}{L} \sum_{l=1}^{L} \frac{\left|Y_{n+l}-\hat{Y}_{n}(l)\right|}{Y_{n+l}} \times 100 \%,
$$

dan persamaan untuk menghitung RMSE adalah sebagai berikut [15]: 


\section{Jumal Matematika, Statistika \& Komputasi}

Kartika Ramadani, Sri Wahyuningsih, Memi Nor Hayati

$$
R M S E=\sqrt{\frac{1}{L} \sum_{l=1}^{L}\left(Y_{n+l}-\hat{Y}_{n}(l)\right)^{2}}
$$

\section{HASIL DAN PEMBAHASAN}

\subsection{Plot Runtun Waktu}

Data yang digunakan pada penelitian ini adalah harga saham PT. Telkom Indonesia Tbk periode 02 Januari 2020 hingga 23 Desember 2020. Jumlah data pengamatan adalah 240 data. Data tersebut diperoleh pada website yahoo finance, yaitu https://finance.yahoo.com. Plot runtun waktu data harga saham PT. Telkom Indonesia Tbk ditampilkan pada Gambar 2.1.

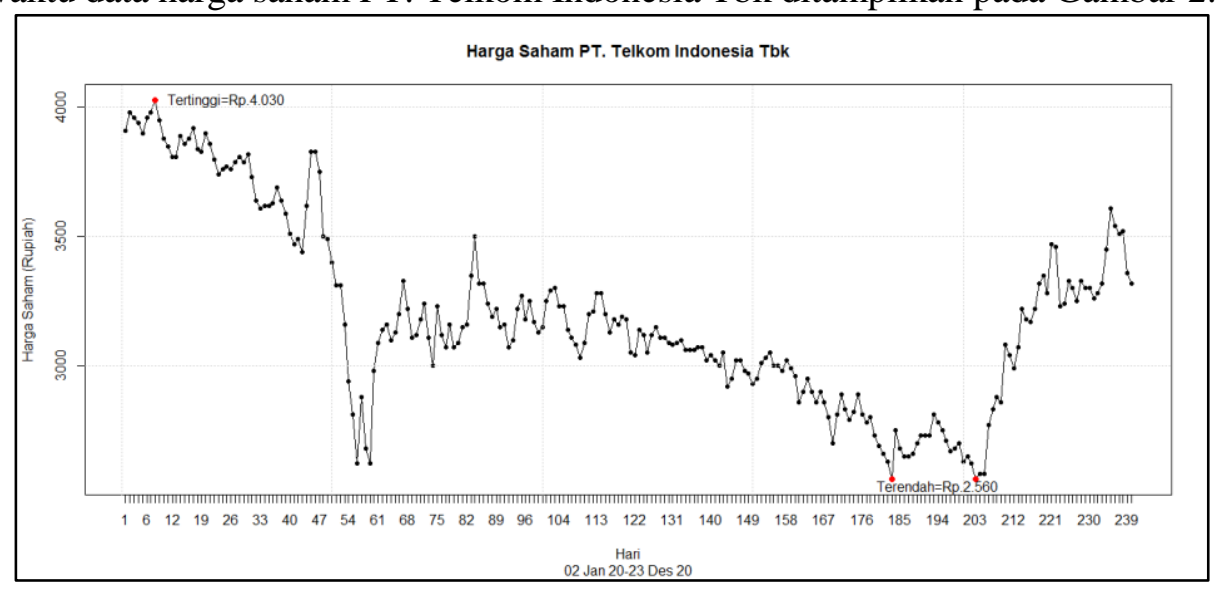

Gambar 2.1 Plot runtun waktu data harga saham PT. Telkom Indonesia Tbk

Berdasarkan Gambar 2.1 terlihat bahwa harga saham PT. Telkom Indonesia Tbk tertinggi pada periode data ke-8. Harga saham PT. Telkom Indonesia Tbk terendah pada periode data ke183 dan data ke-203.

Pada Gambar 2.1 dapat dilihat bahwa harga saham PT. Telkom Indonesia Tbk tidak membentuk pola data yang stasioner, karena terdapat pola trend. Pola trend yang terbentuk adalah trend turun dan trend naik. Pola trend turun terjadi pada periode ke-1 sampai dengan periode data ke-203. Pada periode data ke-204 cenderung mengalami trend naik sampai dengan periode data ke-240. Pada Gambar 2.1 juga memperlihatkan tidak adanya pola seasonal.

\subsection{Pembagian Data Training dan Testing}

Data training adalah data yang digunakan untuk memperoleh model. Data testing adalah data yang digunakan untuk menentukan model terbaik. Pembagian data menggunakan tiga proporsi, yaitu 90:10, 80:20, dan 70:30. Jumlah pembagian data dapat dilihat pada Tebel 2.1.

Tabel 2.1 Pembagian Data Training dan Testing

\begin{tabular}{lllll}
\hline Proporsi & Training & Periode waktu & Testing & Periode waktu \\
\hline 90:10 & 216 & 02 Jan-19 Nov & 24 & 20 Nov-23 Des \\
80:20 & 192 & 02 Jan-13 Okt & 48 & 14 Okt-23 Des \\
70:30 & 168 & 02 Jan-09 Sept & 72 & 10 Sept-23 Des \\
\hline
\end{tabular}

\subsection{Model TSR linier}

\section{Pemodelan}

Model TSR Linier dibuat dengan meregresikan variabel independen terhadap variabel dependen sesuai dengan Persamaan (1.3). Nilai estimasi parameter model diperoleh dengan menggunakan Persamaan (1.4) dan Persamaan (1.5). Berdasarkan perhitungan menggunakan 


\section{Jumal Matematika, Statistika \& Komputasi}

\section{Kartika Ramadani, Sri Wahyuningsih, Memi Nor Hayati}

Persamaan (1.4) dan Persamaan (1.5), diperoleh estimasi model data training TSR linier dari tiga proporsi data yang berbeda pada Tabel 2.2.

Tabel 2.2 Estimasi Model Data Training TSR linier

\begin{tabular}{ll}
\hline Proporsi data training & Model \\
\hline 90 & $\hat{Y}_{t}=3.730,485-5,098 t$ \\
80 & $\hat{Y}_{t}=3.776,706-5,755 t$ \\
70 & $\hat{Y}_{t}=3.775,825-5,742 t$ \\
\hline
\end{tabular}

2. Pemeriksaan Residual White Noise

Pemeriksaan residual white noise menggunakan uji Ljung-Box. Hasil pengujian residual white noise ditampilkan pada Tabel 2.3.

Tabel 2.3 Pemeriksaan Residual White Noise Model TSR Linier

\begin{tabular}{llll}
\hline Proporsi data training & Lag & $\boldsymbol{P}$-value & Keputusan \\
\hline \multirow{4}{*}{90} & 12 & $2,2 \times 10^{-16}$ & $H_{0}$ ditolak \\
& 24 & $2,2 \times 10^{-16}$ & $H_{0}$ ditolak \\
& 36 & $2,2 \times 10^{-16}$ & $H_{0}$ ditolak \\
& 48 & $2,2 \times 10^{-16}$ & $H_{0}$ ditolak \\
60 & $2,2 \times 10^{-16}$ & $H_{0}$ ditolak \\
& 12 & $2,2 \times 10^{-16}$ & $H_{0}$ ditolak \\
& 24 & $2,2 \times 10^{-16}$ & $H_{0}$ ditolak \\
& 36 & $2,2 \times 10^{-16}$ & $H_{0}$ ditolak \\
& 48 & $2,2 \times 10^{-16}$ & $H_{0}$ ditolak \\
& 60 & $2,2 \times 10^{-16}$ & $H_{0}$ ditolak \\
& 12 & $2,2 \times 10^{-16}$ & $H_{0}$ ditolak \\
& 24 & $2,2 \times 10^{-16}$ & $H_{0}$ ditolak \\
& 36 & $2,2 \times 10^{-16}$ & $H_{0}$ ditolak \\
& 48 & $2,2 \times 10^{-16}$ & $H_{0}$ ditolak \\
& 60 & $2,2 \times 10^{-16}$ & $H_{0}$ ditolak \\
\hline
\end{tabular}

Berdasarkan Tabel 2.3 dapat disimpulkan data residual model training TSR linier tidak white noise. Dengan demikian data residual model training TSR linier perlu dihybridkan, karena masih terdapat informasi dari data yang belum ditangkap oleh model training TSR linier.

\section{Menghitung Nilai MAD, MAPE dan RMSE}

Diperoleh nilai MAD, MAPE, dan RMSE dari tiga proporsi data yang berbeda pada Tabel 2.4 .

Tabel 2.4 Nilai MAD, MAPE, dan RMSE Model TSR Linier

\begin{tabular}{llll}
\hline Proporsi data testing & MAD & MAPE (\%) & RMSE \\
\hline 10 & 790,658 & 23,467 & 800,805 \\
20 & 563,754 & 17,151 & 679,359 \\
30 & 393,030 & 12,072 & 554,651 \\
\hline
\end{tabular}




\section{Jumal Matematika, Statistika \& Komputasi}

Kartika Ramadani, Sri Wahyuningsih, Memi Nor Hayati

\subsection{Model ARIMA}

Data residual model TSR linier akan dimodelkan kembali oleh model ARIMA. Pada tahap ini akan dijabarkan pembentukan model dengan proporsi data training 90 .

\section{Identifikasi Model}

Pemeriksaan stasioneritas data dalam variansi dengan menggunakan plot Box-Cox

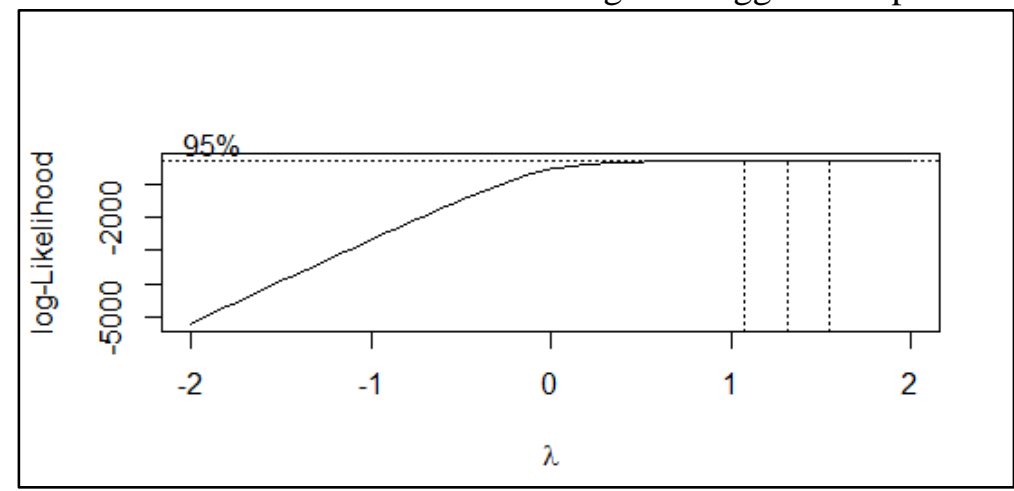

Gambar 2.2 Plot Box-Cox data residual model TSR linier

Diperoleh nilai $\lambda$ sebesar 1,295. Dengan demikian data belum stasioner dalam variansi karena nilai $\lambda$ tidak sama dengan 1, sehingga perlu dilakukan transformasi Box-Cox. Setelah dilakukan transformasi, dilakukan pemeriksaan kembali dan diperoleh nilai $\lambda$ sebesar 1 . Langkah berikutnya adalah pemeriksaan stasioneritas dalam rata-rata. Adapun cara untuk memeriksa stasioneritas dalam rata-rata adalah dengan melihat ACF plot pada Gambar 2.3.

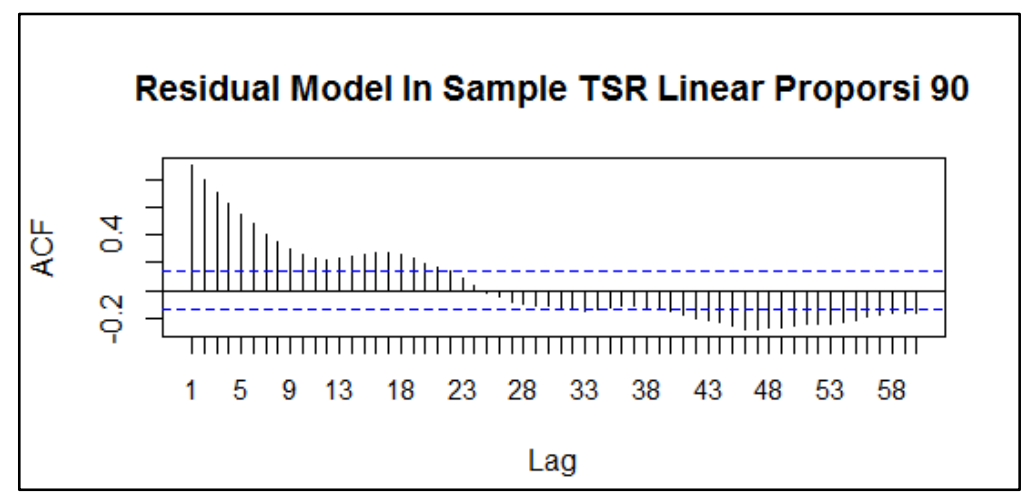

Gambar 2.3 Plot ACF data residual model TSR linier

Pada Gambar 2.3 dapat dilihat bahwa nilai lag pada ACF plot mengalami dies down. Hal ini mengindikasikan bahwa data residual yang telah ditransformasi belum stasioner dalam rata-rata dan perlu dilakukan differencing orde 1. Setelah dilakukan differencing, diperoleh plot ACF sebagai berikut. 


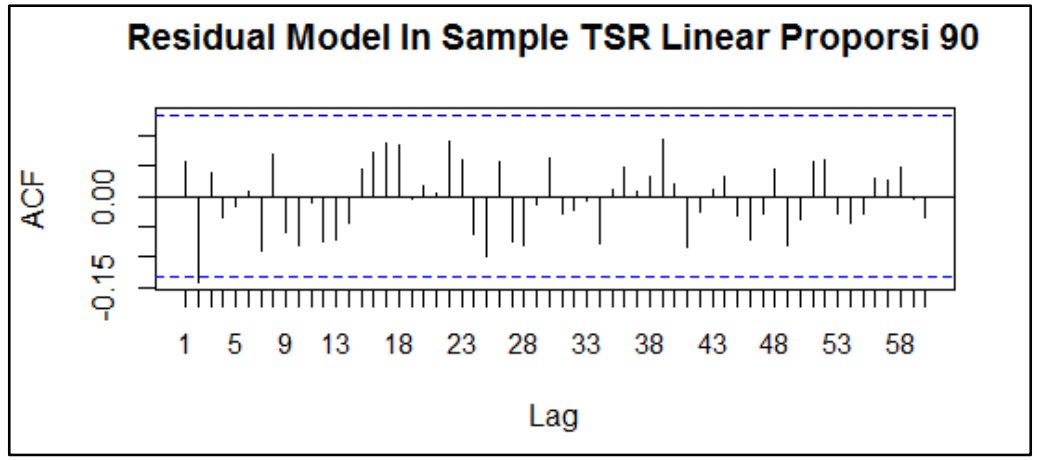

Gambar 2.4 Plot ACF setelah differencing

Berdasarkan Gambar 2.4 dapat dilihat bahwa ACF plot mengalami cut off pada lag 2. Dapat disimpulkan bahwa data residual yang telah ditransformasi dan didifferencing orde 1 telah stasioner dalam rata-rata. Tahap selanjutnya adalah menentukan orde AR (p) dan MA (q) dengan melihat plot ACF pada Gambar 2.4 dan plot PACF berikut.

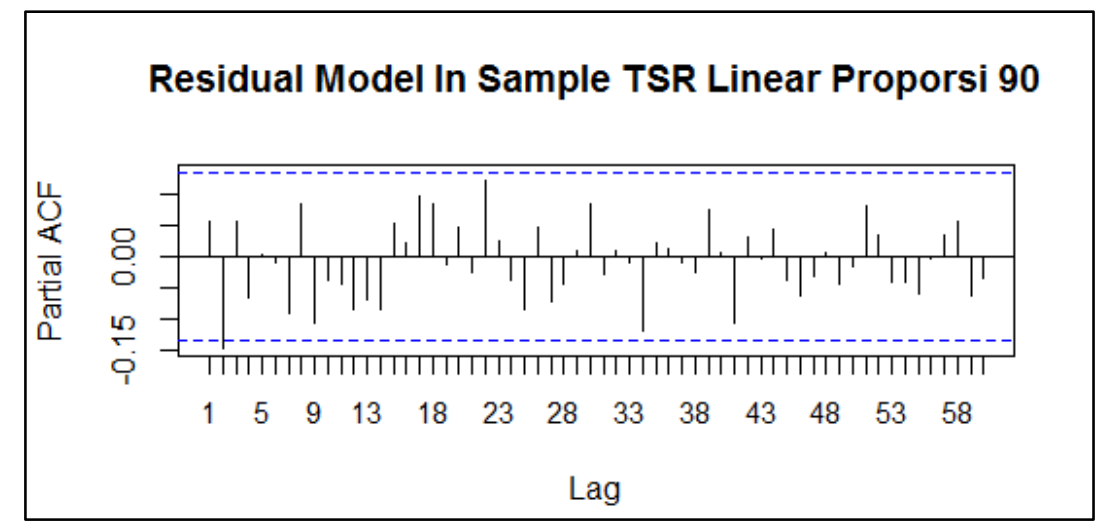

Gambar 2.5 Plot PACF data residual model TSR linier

Pada Gambar 2.4 dapat diketahui bahwa plot ACF mengalami cut off pada lag 2. Kemudian pada Gambar 2.5 dapat diketahui bahwa plot PACF juga mengalami cut off pada lag 2. Dengan demikian, berdasarkan plot ACF dan plot PACF dapat dibentuk model dugaan ARIMA yaitu ARIMA $(0,1,1)$, ARIMA $(1,1,0)$, ARIMA $(0,1,2)$, ARIMA $(2,1,0)$, ARIMA $(1,1,1)$, ARIMA $(2,1,1)$, ARIMA $(1,1,2)$, dan ARIMA $(2,1,2)$.

\section{Estimasi Parameter dan Pengujian Signifikansi Parameter}

Diperoleh hasil estimasi parameter dan pengujian signifikansi parameter yang ditampilkan pada Tabel 2.5.

Tabel 2.5 Estimasi Parameter dan Pengujian Signifikansi Parameter Data Residual Model TSR

\begin{tabular}{lllclll}
\multicolumn{1}{c}{ Linier } \\
\hline No. & Model & $\begin{array}{l}\text { Estimasi } \\
\text { parameter }\end{array}$ & $t_{\text {hitung }}$ & $\begin{array}{l}P- \\
\text { value }\end{array}$ & $t_{\text {tabel }}$ & Keputusan \\
\hline 1 & ARIMA $(0,1,1)$ & $\hat{\theta}_{1}=0,080$ & 0,981 & 0,328 & 1,971 & $\begin{array}{l}H_{0} \text { gagal } \\
\text { ditolak }\end{array}$ \\
2 & ARIMA $(1,1,0)$ & $\hat{\phi}_{1}=0,056$ & 0,826 & 0,410 & 1,971 & $\begin{array}{l}H_{0} \text { gagal } \\
\text { ditolak }\end{array}$ \\
3 & ARIMA $(0,1,2)$ & $\hat{\theta}_{1}=0,081$ & 1,194 & 0,234 & 1,971 & $H_{0}$ gagal \\
\hline
\end{tabular}




\section{Jurnal Matematika, Statistika \& Komputasi}

Kartika Ramadani, Sri Wahyuningsih, Memi Nor Hayati

\begin{tabular}{|c|c|c|c|c|c|c|}
\hline & & & & & & ditolak \\
\hline & & $\hat{\theta}_{2}=-0,159$ & $-2,345$ & 0,020 & 1,971 & $H_{0}$ ditolak \\
\hline 4 & ARIMA $(2,1,0)$ & $\hat{\phi}_{1}=0,065$ & 0,957 & 0,340 & 1,971 & $\begin{array}{l}H_{0} \text { gagal } \\
\text { ditolak }\end{array}$ \\
\hline & & $\hat{\phi}_{2}=-0,145$ & $-2,145$ & 0,033 & 1,971 & $H_{0}$ ditolak \\
\hline 5 & 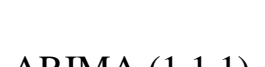 & $\hat{\phi}_{1}=-0,528$ & $-2,682$ & 0,008 & 1,971 & $H_{0}$ ditolak \\
\hline$J$ & RIN⿴囗十 $(1,1,1)$ & $\hat{\theta}_{1}=0,647$ & 3,759 & 0,000 & 1,971 & $H_{0}$ ditolak \\
\hline
\end{tabular}

Tabel 2.5 Estimasi Parameter dan Pengujian Signifikansi Parameter Data Residual Model TSR Linier (lanjutan)

\begin{tabular}{|c|c|c|c|c|c|c|}
\hline No. & Model & $\begin{array}{l}\text { Estimasi } \\
\text { parameter }\end{array}$ & $t_{\text {hitung }}$ & $\begin{array}{l}P \text { - } \\
\text { value }\end{array}$ & $t_{\text {tabel }}$ & Keputusan \\
\hline \multirow[t]{3}{*}{6} & ARIMA $(2,1,1)$ & $\hat{\phi}_{1}=-0,355$ & $-1,352$ & 0,178 & 1,971 & $\begin{array}{c}H_{0} \text { gagal } \\
\text { ditolak }\end{array}$ \\
\hline & & $\hat{\phi}_{2}=-0,124$ & $-1,644$ & 0,102 & 1,971 & $\begin{array}{c}H_{0} \text { gagal } \\
\text { ditolak }\end{array}$ \\
\hline & & $\hat{\theta}_{1}=0,431$ & 1,662 & 0,098 & 1,971 & $\begin{array}{c}H_{0} \text { gagal } \\
\text { ditolak }\end{array}$ \\
\hline \multirow[t]{3}{*}{7} & ARIMA $(1,1,2)$ & $\hat{\phi}_{1}=-0,164$ & $-0,465$ & 0,643 & 1,971 & $\begin{array}{c}H_{0} \text { gagal } \\
\text { ditolak }\end{array}$ \\
\hline & & $\hat{\theta}_{1}=0,241$ & 0,686 & 0,493 & 1,971 & $\begin{array}{c}H_{0} \text { gagal } \\
\text { ditolak }\end{array}$ \\
\hline & & $\hat{\theta}_{2}=-0,139$ & $-1,672$ & 0,096 & 1,971 & $\begin{array}{c}H_{0} \text { gagal } \\
\text { ditolak }\end{array}$ \\
\hline \multirow[t]{4}{*}{8} & ARIMA $(2,1,2)$ & $\hat{\phi}_{1}=-1,465$ & $-13,076$ & $\begin{array}{c}2,200 \times \\
10^{-16}\end{array}$ & 1,971 & $H_{0}$ ditolak \\
\hline & & $\hat{\phi}_{2}=-0,799$ & $-8,225$ & $\begin{array}{c}1,987 \times \\
10^{-14}\end{array}$ & 1,971 & $H_{0}$ ditolak \\
\hline & & $\hat{\theta}_{1}=1,590$ & 15,488 & $\begin{array}{c}2,200 \times \\
10^{-16}\end{array}$ & 1,971 & $H_{0}$ ditolak \\
\hline & & $\hat{\theta}_{2}=0,865$ & 9,607 & $\begin{array}{c}2,200 \times \\
10^{-16}\end{array}$ & 1,971 & $H_{0}$ ditolak \\
\hline
\end{tabular}

Berdasarkan Tabel 2.5 dapat dilihat bahwa model yang dapat digunakan adalah model ARIMA $(1,1,1)$ dan ARIMA $(2,1,2)$.

\section{Pemeriksaan Diagnostik}

Pemeriksaan diagnostik terdiri dari pengujian residual white noise dan residual berdistribusi normal. Pengujian residual white noise menggunakan uji Ljung-Box sedangkan pengujian residual berdistribusi normal menggunakan uji Kolmogorov-Smirnov.

Berikut adalah hasil pengujian residual white noise yang ditampilkan dalam bentuk grafik pada Gambar 2.6. 


\section{Jumal Matematika, Statistika \& Komputasi \\ Kartika Ramadani, Sri Wahyuningsih, Memi Nor Hayati}

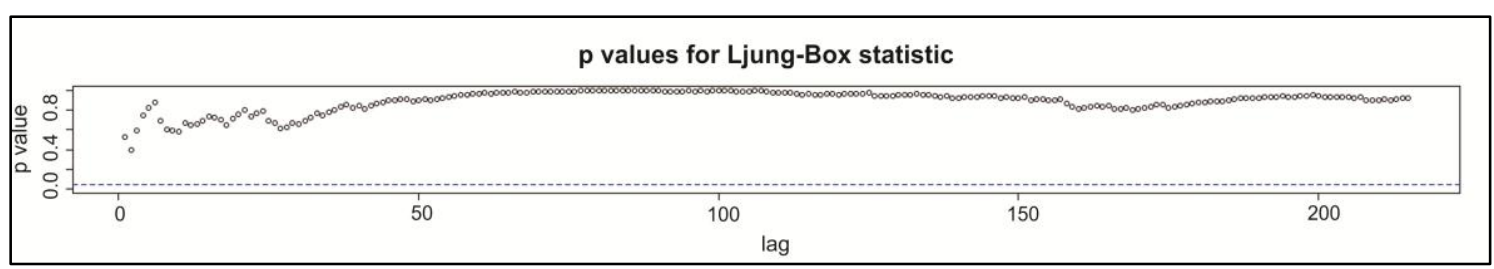

(a)

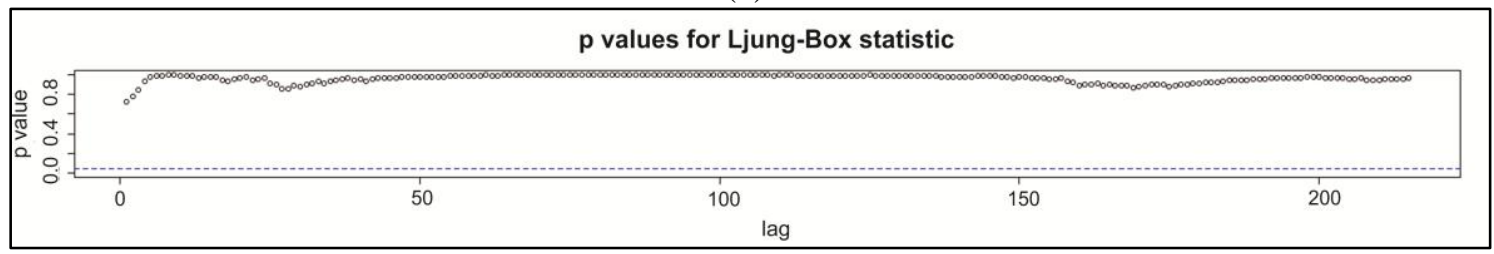

(b)

Gambar 2.6 Pengujian residual white noise pada model ARIMA $(1,1,1)$ dan model ARIMA $(2,1,2)$

Berdasarkan Gambar 2.6, diketahui bahwa Gambar 2.6(a) adalah pengujian residual model ARIMA $(1,1,1)$ dan Gambar 2.6(b) adalah pengujian residual model ARIMA $(2,1,2)$. Dapat dilihat pada Gambar 2.6(a) dan 2.6(b) bahwa tiap lag memiliki $p$-value $>\alpha=0,05$ sehingga dapat diputuskan $H_{0}$ gagal ditolak dan dapat disimpulkan data residual model ARIMA $(1,1,1)$ dan model ARIMA $(2,1,2)$ memenuhi asumsi white noise. Asumsi selanjutnya yang diperiksa adalah apakah data residual tersebut berdistribusi normal. Hasil pengujian residual berdistribusi normal ditampilkan pada Tabel 2.6.

Table 2.6 Pengujian Residual Berdistribusi Normal Pada Model ARIMA $(1,1,1)$ dan Model ARIMA $(2,1,2)$

\begin{tabular}{llrrl}
\hline No. & Model & \multicolumn{1}{l}{$D$} & \multicolumn{1}{l}{ P-value } & Keputusan \\
\hline 1 & ARIMA $(1,1,1)$ & 0,067 & 0,288 & $H_{0}$ gagal ditolak \\
2 & ARIMA $(2,1,2)$ & 0,074 & 0,186 & $H_{0}$ gagal ditolak \\
\hline
\end{tabular}

Berdasarkan Tabel 2.6 dapat diketahui bahwa model ARIMA $(1,1,1)$ dan model ARIMA $(2,1,2)$ memenuhi asumsi residual berdistribusi normal. Model ARIMA $(1,1,1)$ dan ARIMA $(2,1,2)$ secara matematis dapat dituliskan pada persamaan berikut:

1. $\operatorname{ARIMA}(1,1,1)$

$$
\begin{aligned}
& Z_{t}=Z_{t-1}+\phi_{1} Z_{t-1}-\phi_{1} Z_{t-2}+a_{t}+\theta_{1} a_{t-1} \\
& \hat{Z}_{t}=\hat{Z}_{t-1}+(-0,528) \hat{Z}_{t-1}-(-0,528) \hat{Z}_{t-2}+\hat{a}_{t}+0,647 \hat{a}_{t-1} \\
& \hat{Z}_{t}=\hat{Z}_{t-1}-0,528 \hat{Z}_{t-1}+0,528 \hat{Z}_{t-2}+\hat{a}_{t}+0,647 \hat{a}_{t-1}
\end{aligned}
$$

2. $\operatorname{ARIMA}(2,1,2)$

$$
\begin{aligned}
& Z_{t}=Z_{t-1}+\phi_{1} Z_{t-1}-\phi_{1} Z_{t-2}+\phi_{2} Z_{t-1}-\phi_{2} Z_{t-3}+a_{t}+\theta_{1} a_{t-1}+\theta_{2} a_{t-2} \\
& \hat{Z}_{t}=\hat{Z}_{t-1}+(-1,465) \hat{Z}_{t-1}-(-1,465) \hat{Z}_{t-2}+(-0,799) \hat{Z}_{t-1}-(-0,799) \hat{Z}_{t-3} \\
& +\hat{a}_{t}+1,589 \hat{a}_{t-1}+0,865 \hat{a}_{t-2} \\
& \hat{Z}_{t}=\hat{Z}_{t-1}-1,465 \hat{Z}_{t-1}+1,465 \hat{Z}_{t-2}-0,799 \hat{Z}_{t-1}+0,799 \hat{Z}_{t-3}+ \\
& \hat{a}_{t}+1,589 \hat{a}_{t-1}+0,865 \hat{a}_{t-2}
\end{aligned}
$$

Dengan menggunakan tahapan yang sama, diperoleh model ARIMA untuk proporsi data training 80 pada persamaan berikut:

1. $\operatorname{ARIMA}(1,1,1)$

$$
Z_{t}=Z_{t-1}+\phi_{1} Z_{t-1}-\phi_{1} Z_{t-2}+a_{t}+\theta_{1} a_{t-1}
$$




\section{Jumal Matematika, Statistika \& Komputasi}

\section{Kartika Ramadani, Sri Wahyuningsih, Memi Nor Hayati}

$$
\begin{aligned}
& \hat{Z}_{t}=\hat{Z}_{t-1}+(-0,515) \hat{Z}_{t-1}-(-0,515) \hat{Z}_{t-2}+\hat{a}_{t}+0,650 \hat{a}_{t-1} \\
& \hat{Z}_{t}=\hat{Z}_{t-1}-0,515 \hat{Z}_{t-1}+0,515 \hat{Z}_{t-2}+\hat{a}_{t}+0,650 \hat{a}_{t-1}
\end{aligned}
$$

2. $\operatorname{ARIMA}(2,1,1)$

$$
\begin{aligned}
& Z_{t}=Z_{t-1}+\phi Z_{t-1}-\phi_{1} Z_{t-2}+\phi_{2} Z_{t-2}-\phi_{2} Z_{t-3}+a_{t}+\theta_{1} a_{t-1} \\
& \hat{Z}_{t}=\hat{Z}_{t-1}+0,870 \hat{Z}_{t-1}-0,870 \hat{Z}_{t-2}+(-0,204) Z_{t-2}-(-0,204) Z_{t-3} \\
& +\hat{a}_{t}+(-0,858) \hat{a}_{t-1} \\
& \hat{Z}_{t}=\hat{Z}_{t-1}+0,870 \hat{Z}_{t-1}-0,870 \hat{Z}_{t-2}-0,204 Z_{t-2}+0,204 Z_{t-3} \\
& +\hat{a}_{t}-0,858 \hat{a}_{t-1}
\end{aligned}
$$

3. ARIMA $(1,1,2)$

$$
\begin{aligned}
& Z_{t}=Z_{t-1}+\phi_{1} Z_{t-1}-\phi_{1} Z_{t-2}+a_{t}+\theta_{1} a_{t-1}+\theta_{2} a_{t-2} \\
& \hat{Z}_{t}=\hat{Z}_{t-1}+0,594 \hat{Z}_{t-1}-0,594 \hat{Z}_{t-2}+\hat{a}_{t}+(-0,557) \hat{a}_{t-1}+(-0,272) \hat{a}_{t-2} \\
& \hat{Z}_{t}=\hat{Z}_{t-1}+0,594 \hat{Z}_{t-1}-0,594 \hat{Z}_{t-2}+\hat{a}_{t}-0,557 \hat{a}_{t-1}-0,272 \hat{a}_{t-2}
\end{aligned}
$$

Tahapan yang sama juga diterapkan pada proporsi data training 70 dan diperoleh model ARIMA pada persamaan berikut:

1. ARIMA $(1,1,1)$

$$
\begin{aligned}
& Z_{t}=Z_{t-1}+\phi_{1} Z_{t-1}-\phi_{1} Z_{t-2}+a_{t}+\theta_{1} a_{t-1} \\
& \hat{Z}_{t}=\hat{Z}_{t-1}+(-0,484) \hat{Z}_{t-1}-(-0,484) \hat{Z}_{t-2}+\hat{a}_{t}+0,644 \hat{a}_{t-1} \\
& \hat{Z}_{t}=\hat{Z}_{t-1}-0,484 \hat{Z}_{t-1}+0,484 \hat{Z}_{t-2}+\hat{a}_{t}+0,644 \hat{a}_{t-1}
\end{aligned}
$$

2. $\operatorname{ARIMA}(2,1,1)$

$$
\begin{aligned}
& Z_{t}=Z_{t-1}+\phi_{1} Z_{t-1}-\phi_{1} Z_{t-2}+\phi_{2} Z_{t-2}-\phi_{2} Z_{t-3}+a_{t}+\theta_{1} a_{t-1} \\
& \hat{Z}_{t}=\hat{Z}_{t-1}+0,903 \hat{Z}_{t-1}-0,903 \hat{Z}_{t-2}+(-0,222) Z_{t-2}-(-0,222) Z_{t-3}+\hat{a}_{t} \\
& +(-0,857) \hat{a}_{t-1} \\
& \hat{Z}_{t}=\hat{Z}_{t-1}+0,903 \hat{Z}_{t-1}-0,903 \hat{Z}_{t-2}-0,222 Z_{t-2}+0,222 Z_{t-3}+\hat{a}_{t} \\
& -0,857 \hat{a}_{t-1}
\end{aligned}
$$

3. $\operatorname{ARIMA}(1,1,2)$

$$
\begin{aligned}
& Z_{t}=Z_{t-1}+\phi_{1} Z_{t-1}-\phi_{1} Z_{t-2}+a_{t}+\theta_{1} a_{t-1}+\theta_{2} a_{t-2} \\
& \hat{Z}_{t}=\hat{Z}_{t-1}+0,615 \hat{Z}_{t-1}-0,615 \hat{Z}_{t-2}+\hat{a}_{t}+(-0,542) \hat{a}_{t-1}+(-0,288) \hat{a}_{t-2} \\
& \hat{Z}_{t}=\hat{Z}_{t-1}+0,615 \hat{Z}_{t-1}-0,615 \hat{Z}_{t-2}+\hat{a}_{t}-0,542 \hat{a}_{t-1}-0,288 \hat{a}_{t-2}
\end{aligned}
$$

\subsection{Model Hybrid TSR-ARIMA}

Setelah diperoleh model TSR linier dan model ARIMA dari residual TSR linier, maka selanjutnya membentuk model hybrid TSR linier-ARIMA

\section{Estimasi Model Hybrid TSR-ARIMA}

Diperoleh model hybrid TSR linier-ARIMA sebagai berikut:

a. Proporsi 90:10

Model 1: Hybrid TSR linier-ARIMA $(1,1,1)$

$$
\hat{H}_{t}=3.730,485-5,098 t+\hat{Z}_{t-1}-0,528 \hat{Z}_{t-1}+0,528 \hat{Z}_{t-2}+\hat{a}_{t}+0,647 \hat{a}_{t-1}
$$

Model 2: Hybrid TSR linier-ARIMA $(2,1,2)$

$$
\begin{aligned}
& \hat{H}_{t}=3.730,485-5,098 t+\hat{Z}_{t-1}-1,465 \hat{Z}_{t-1}+1,465 \hat{Z}_{t-2}-0,799 \hat{Z}_{t-1} \\
& +0,799 \hat{Z}_{t-3}+\hat{a}_{t}+1,589 \hat{a}_{t-1}+0,865 \hat{a}_{t-2}
\end{aligned}
$$

Diperoleh hasil peramalan dari model hybrid TSR linier-ARIMA proporsi 90:10 pada Tabel 2.7. 
Jumal Matematika, Statistika \& Komputasi

Kartika Ramadani, Sri Wahyuningsih, Memi Nor Hayati

Tabel 2.7 Hasil Peramalan Model Hybrid TSR linier-ARIMA dengan Proporsi 90:10

\begin{tabular}{llllllll}
\hline \multirow{2}{*}{ Periode } & Tanggal & \multicolumn{3}{l}{ Harga saham } & & & \multicolumn{2}{l}{ Harga saham } \\
\cline { 3 - 4 } \cline { 7 - 8 } & & Model & $\begin{array}{l}\text { Model } \\
\text { Periode }\end{array}$ & Tanggal & & Model & Model \\
& & & 2 & & & 1 & 2 \\
\hline 241 & $04 / 01 / 2021$ & 3.322 & 3.340 & 251 & $18 / 01 / 2021$ & 3.268 & 3.279 \\
242 & $05 / 01 / 2021$ & 3.313 & 3.308 & 252 & $19 / 01 / 2021$ & 3.263 & 3.264 \\
243 & $06 / 01 / 2021$ & 3.310 & 3.322 & 253 & $20 / 01 / 2021$ & 3.258 & 3.268 \\
244 & $07 / 01 / 2021$ & 3.303 & 3.310 & 254 & $21 / 01 / 2021$ & 3.253 & 3.258 \\
245 & $08 / 01 / 2021$ & 3.300 & 3.299 & 255 & $22 / 01 / 2021$ & 3.248 & 3.253 \\
246 & $11 / 01 / 2021$ & 3.293 & 3.308 & 256 & $25 / 01 / 2021$ & 3.243 & 3.252 \\
247 & $12 / 01 / 2021$ & 3.289 & 3.287 & 257 & $26 / 01 / 2021$ & 3.238 & 3.241 \\
248 & $13 / 01 / 2021$ & 3.283 & 3.295 & 258 & $27 / 01 / 2021$ & 3.233 & 3.241 \\
249 & $14 / 01 / 2021$ & 3.278 & 3.284 & 259 & $28 / 01 / 2021$ & 3.227 & 3.232 \\
250 & $15 / 01 / 2021$ & 3.273 & 3.277 & 260 & $29 / 01 / 2021$ & 3.222 & 3.228 \\
& & & & & & & \\
\hline
\end{tabular}

b. Proporsi 80:20

Model 1: Hybrid TSR linier-ARIMA $(1,1,1)$

$$
\begin{aligned}
& \hat{H}_{t}=3.776,706-5,755 t+\hat{Z}_{t-1}-0,515 \hat{Z}_{t-1}+0,515 \hat{Z}_{t-2} \\
& +\hat{a}_{t}+0,650 \hat{a}_{t-1}
\end{aligned}
$$

Model 2: Hybrid TSR linier-ARIMA $(2,1,1)$

$$
\begin{aligned}
& \hat{H}_{t}=3.776,706-5,755 t+\hat{Z}_{t-1}+0,870 \hat{Z}_{t-1}-0,870 \hat{Z}_{t-2} \\
& -0,204 Z_{t-2}+0,204 Z_{t-3}+\hat{a}_{t}-0,858 \hat{a}_{t-1}
\end{aligned}
$$

Model 3: Hybrid TSR linier-ARIMA $(1,1,2)$

$$
\begin{aligned}
& \hat{H}_{t}=3.776,706-5,755 t+\hat{Z}_{t-1}+0,594 \hat{Z}_{t-1}-0,594 \hat{Z}_{t-2}+\hat{a}_{t} \\
& -0,557 \hat{a}_{t-1}-0,272 \hat{a}_{t-2}
\end{aligned}
$$

\begin{tabular}{|c|c|c|c|c|c|c|c|}
\hline \multirow[b]{2}{*}{ Periode } & \multicolumn{3}{|c|}{ Harga Saham } & \multirow[b]{2}{*}{ Periode } & \multicolumn{3}{|c|}{ Harga Saham } \\
\hline & $\begin{array}{l}\text { Model } \\
1\end{array}$ & $\begin{array}{l}\text { Model } \\
2\end{array}$ & $\begin{array}{l}\text { Model } \\
3\end{array}$ & & $\begin{array}{l}\text { Model } \\
1\end{array}$ & $\begin{array}{l}\text { Model } \\
2\end{array}$ & $\begin{array}{l}\text { Model } \\
3\end{array}$ \\
\hline 241 & 3.323 & 3.340 & 3.340 & 251 & 3.262 & 3.275 & 3.280 \\
\hline 242 & 3.312 & 3.325 & 3.330 & 252 & 3.256 & 3.269 & 3.274 \\
\hline 243 & 3.309 & 3.321 & 3.326 & 253 & 3.251 & 3.263 & 3.268 \\
\hline 244 & 3.302 & 3.316 & 3.320 & 254 & 3.245 & 3.258 & 3.262 \\
\hline 245 & 3.297 & 3.309 & 3.314 & 255 & 3.239 & 3.252 & 3.256 \\
\hline 246 & 3.290 & 3.304 & 3.308 & 256 & 3.233 & 3.246 & 3.251 \\
\hline 247 & 3.285 & 3.298 & 3.303 & 257 & 3.228 & 3.240 & 3.245 \\
\hline 248 & 3.279 & 3.292 & 3.297 & 258 & 3.222 & 3.235 & 3.239 \\
\hline 249 & 3.274 & 3.286 & 3.291 & 259 & 3.216 & 3.229 & 3.233 \\
\hline 250 & 3.268 & 3.281 & 3.285 & 260 & 3.210 & 3.223 & 3.228 \\
\hline
\end{tabular}

Diperoleh hasil peramalan dari model hybrid TSR linier-ARIMA proporsi data 80:20 pada Tabel 2.8.

Tabel 2.8 Hasil Peramalan Model Hybrid TSR linier-ARIMA dengan Proporsi 80:20

c. Proporsi 70:30

Model 1: Hybrid TSR linier-ARIMA $(1,1,1)$ 


\section{Jurnal Matematika, Statistika \& Komputasi}

Kartika Ramadani, Sri Wahyuningsih, Memi Nor Hayati

$$
\begin{aligned}
& \hat{H}_{t}=3.775,825-5,742 t+\hat{Z}_{t-1}-0,484 \hat{Z}_{t-1}+0,484 \hat{Z}_{t-2} \\
& +\hat{a}_{t}+0,644 \hat{a}_{t-1}
\end{aligned}
$$

Model 2: Hybrid TSR linier-ARIMA $(2,1,1)$

$$
\begin{aligned}
& \hat{H}_{t}=3.775,825-5,742 t+\hat{Z}_{t-1}+0,903 \hat{Z}_{t-1}-0,903 \hat{Z}_{t-2} \\
& -0,222 Z_{t-2}+0,222 Z_{t-3}+\hat{a}_{t}-0,857 \hat{a}_{t-1}
\end{aligned}
$$

Model 3: Hybrid TSR linier-ARIMA $(1,1,2)$

$$
\begin{aligned}
& \hat{H}_{t}=3.775,825-5,742 t+\hat{Z}_{t-1}+0,615 \hat{Z}_{t-1}-0,615 \hat{Z}_{t-2} \\
& +\hat{a}_{t}-0,542 \hat{a}_{t-1}-0,288 \hat{a}_{t-2}
\end{aligned}
$$

Diperoleh hasil peramalan dari model hybrid TSR linier-ARIMA proporsi data 70:30 yang ditampilkan pada Tabel 2.9.

Tabel 2.9 Hasil Peramalan Model Hybrid TSR linier-ARIMA dengan Proporsi 70:30

\begin{tabular}{lllllllll}
\hline & \multicolumn{4}{c}{ Harga Saham } & & \multicolumn{3}{c}{ Harga Saham } \\
\cline { 2 - 4 } \cline { 7 - 9 } Periode & Model & Model & Model & Periode & Model & Model & \multicolumn{1}{l}{ Model } \\
241 & 1 & 2 & 3 & & & 2 & 3 \\
242 & 3.324 & 3.340 & 3.339 & 251 & & 3.263 & 3.275 & 3.278 \\
243 & 3.313 & 3.325 & 3.328 & 252 & & 3.257 & 3.270 & 3.272 \\
244 & 3.310 & 3.321 & 3.324 & 253 & & 3.252 & 3.263 & 3.266 \\
245 & 3.303 & 3.316 & 3.318 & 254 & & 3.246 & 3.258 & 3.261 \\
246 & 3.298 & 3.310 & 3.312 & 255 & & 3.240 & 3.252 & 3.255 \\
247 & 3.292 & 3.304 & 3.306 & 256 & & 3.234 & 3.247 & 3.249 \\
248 & 3.286 & 3.298 & 3.301 & 257 & & 3.229 & 3.241 & 3.243 \\
249 & 3.280 & 3.292 & 3.295 & 258 & 3.223 & 3.235 & 3.238 \\
250 & 3.275 & 3.286 & 3.290 & 259 & & 3.217 & 3.229 & 3.232 \\
\hline
\end{tabular}

\section{Menghitung Nilai MAD, MAPE, dan RMSE}

Diperoleh nilai MAD, MAPE, dan RMSE dari tiga proporsi data testing yang berbeda pada tabel berikut.

Tabel 2.10 Nilai MAD, MAPE, dan RMSE Model Hybrid TSR-ARIMA

\begin{tabular}{lllll}
\hline $\begin{array}{l}\text { Proporsi } \\
\text { data } \\
\text { testing }\end{array}$ & Model Hybrid & MAD & MAPE (\%) & RMSE \\
\hline 10 & TSR linier-ARIMA (1,1,1) & 66,994 & 1,986 & 89,514 \\
& TSR linier-ARIMA (2,1,2) & 66,271 & 1,963 & 87,792 \\
20 & TSR linier-ARIMA (1,1,1) & 61,437 & 1,955 & 84,934 \\
& TSR linier-ARIMA (2,1,1) & 59,200 & 1,887 & 84,095 \\
& TSR linier-ARIMA (1,1,2) & 59,400 & 1,894 & 84,363 \\
30 & TSR linier-ARIMA (1,1,1) & 57,778 & 1,914 & 79,446 \\
& TSR linier-ARIMA (2,1,1) & 56,595 & 1,880 & 78,663 \\
& TSR linier-ARIMA (1,1,2) & 56,642 & 1,881 & 78,746 \\
\hline
\end{tabular}

Pada Tabel 2.10 dapat dilihat bahwa seluruh model hybrid memiliki nilai MAD yang tidak jauh berbeda, begitu juga pada nilai MAPE dan RMSE. Adapun nilai MAPE yang diperoleh pada seluruh model hybrid bernilai dibawah 10\%, sehingga dapat disimpulkan bahwa seluruh model hybrid pada penelitian ini merupakan model peramalan yang sangat baik dalam memodelkan dan meramalkan harga saham PT. Telkom Indonesia Tbk. Dari seluruh model hybrid, terdapat satu model hybrid yang memiliki nilai MAD, MAPE, dan RMSE terkecil, yaitu 


\section{Jurnal Matematika, Statistika \& Komputasi \\ Kartika Ramadani, Sri Wahyuningsih, Memi Nor Hayati}

model hybrid TSR linier-ARIMA $(2,1,1)$ dengan proporsi data testing 30 dan training 70. Berikut akan ditampilkan grafik prediksi dan peramalan harga saham PT. Telkom Indonesia Tbk dari model terbaik.

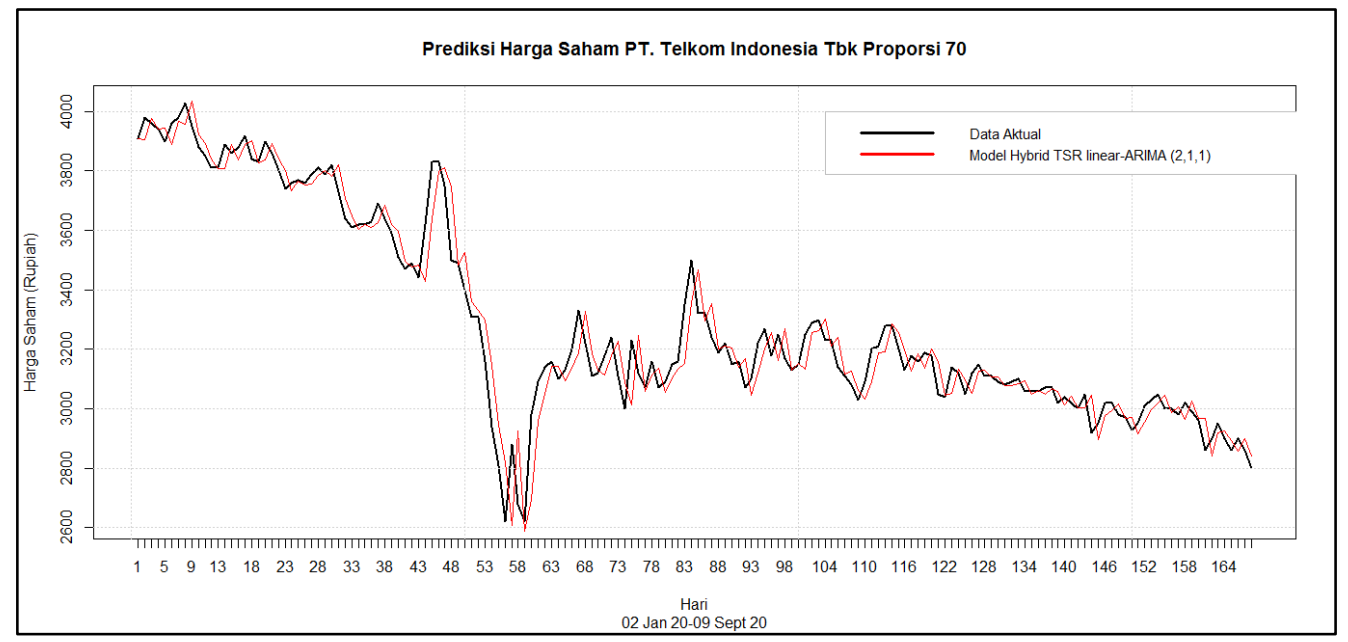

Gambar 2.7 Prediksi harga saham PT. Telkom Indonesia Tbk

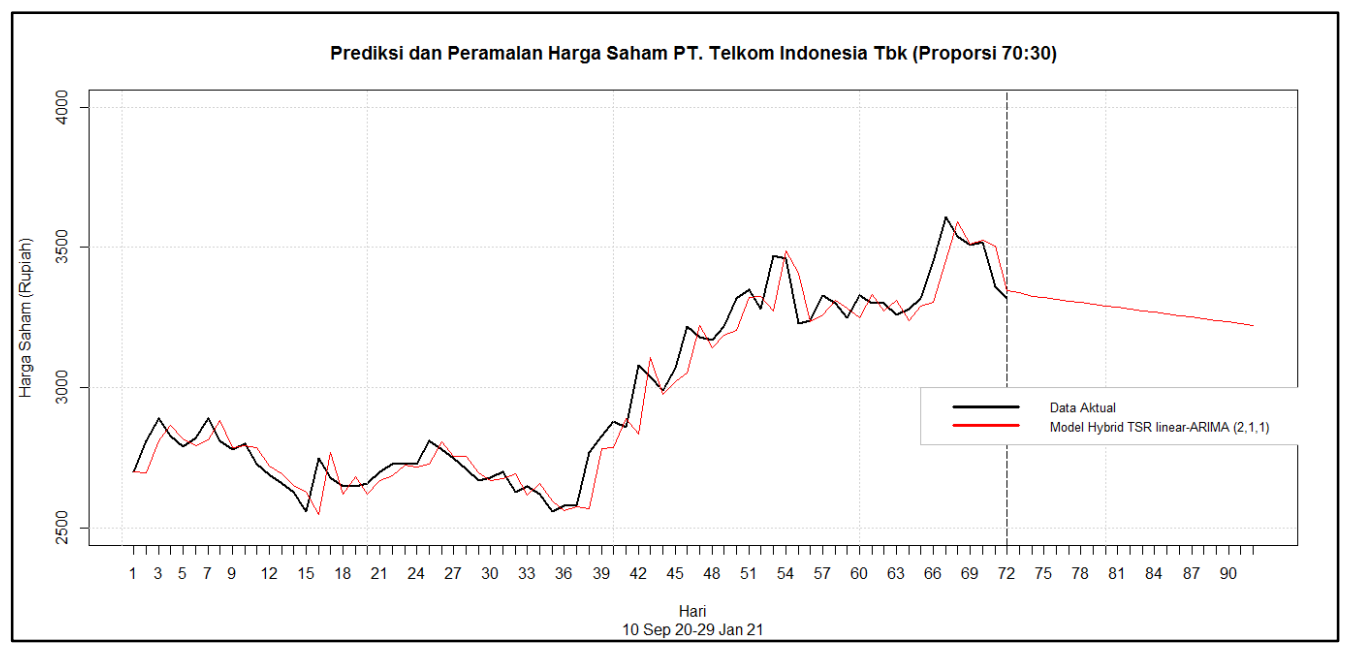

Gambar 2.8 Prediksi dan peramalan harga saham PT. Telkom Indonesia Tbk

Pada Gambar 2.7, model hybrid TSR linier-ARIMA $(2,1,1)$ dengan proporsi 70 memiliki hasil prediksi yang menyerupai pola data aktual. Kemudian pada Gambar 2.8, dari data ke 1 sampai dengan data ke 72 merupakan data aktual dan prediksi berdasarkan data testing. Data hasil peramalan dimulai pada data ke 73 sampai dengan 92 yang merupakan peramalan harga saham PT. Telkom Indonesia Tbk periode 04 Januari 2021 sampai dengan 29 Januari 2021. Pola yang terbentuk pada data peramalan membentuk pola trend turun.

\section{KESIMPULAN DAN SARAN}

\subsection{Kesimpulan}

Berdasarkan hasil penelitian, diperoleh model terbaik, yaitu model hybrid TSR linierARIMA $(2,1,1)$ dengan proporsi 70:30. Model hybrid terbaik memiliki nilai MAD sebesar 56,595, nilai MAPE sebesar 1,880\%, dan nilai RMSE sebesar 78,663, sedangkan model TSR linier dengan proporsi 70:30 memiliki nilai MAD sebesar 393,030, nilai MAPE sebesar 12,072\%, dan nilai RMSE sebesar 554,651. Hal ini dapat disimpulkan bahwa dalam penelitian ini model hybrid lebih baik dibandingkan model TSR linier. Hasil peramalan harga saham PT. Telkom Indonesia Tbk oleh model terbaik menunjukkan pola trend naik. 


\section{Jumal Matematika, Statistika \& Komputasi \\ Kartika Ramadani, Sri Wahyuningsih, Memi Nor Hayati}

\subsection{Saran}

Saran untuk penelitian selanjutnya, dapat menggunakan penggabungan model peramalan dengan struktur gabungan linier- non linier, contohnya model hybrid TSR linier - Radial Basis Function (RBF). Harga saham yang bersifat tidak menentu dan sering ditemukan bersifat fluktuatif dapat menyebabkan harga saham menjadi data yang non linier.

\section{DAFTAR PUSTAKA}

[1] Aswi \& Sukarna, 2006. Analisis Deret Waktu: Teori dan Aplikasi. Makassar: Andira Publisher.

[2] Bowerman, B.L. \& O’Connell R.T., 1987. Time Series Forecasting: Unified Concepts And Computer Implementation: Second Edition. United States of America: PWS Publishers.

[3] Box, G.E.P. \& Cox, D.R., 1964. An Analysis of Transformations. Journal of the Royal Statistical Society. Series B (Methodological), Vol. 26, No. 2, 211-252.

[4] Daniel, W.W., 2000. Applied Nonparametric Statistics (2nd Ed.). Boston: Duxbury Press.

[5] Hajirahimi, Z. \& Mehdi K., 2019. Hybrid structures in time series modeling and forecasting: A review. Engineering Applications of Artificial Intelligence, Vol. 89, 83-85.

[6] Hejase, H.A.N. \& Ali H.A., 2012. Time Series Regression Model For Prediction Of Mean Daily Global Solar Radiation In Al-Ain UEA. International Scholarly Research Network (ISRN) Renewable Energy. Vol. 2012, 1-9.

[7] Hyndman, R.J. \& Athanasopoulos, G., 2018. Forecasting: Principles and Practice: Second Edition. Monash University, Australia. https://otexts.com/fpp2/. [10 November 2021].

[8] Jannah, M. \& Indah N.F.H., 2019. Penaksiran Parameter Model Autoregressive Orde (1) Dengan Menggunakan Metode Likelihood Maksimum. Mathematics \& Applications Journal, Vol. 1, No. 2, 43-44

[9] Makridakis, S., Wheelwright S. C., \& McGee V. E., 1999. Metode dan Aplikasi Peramalan, Jilid 1. Jakarta: Erlangga.

[10] Montgomery, D.C. \& Johnson L.A., 1998. Forecasting and time series analysis. United States of America: McGraw-Hill Inc.

[11] Oberstone, J., 1990. Management Science: Concepts, Insights, and Applications. New York: West Publisher Co.

[12] PT. Telkom Indonesia, 2020. Tentang Telkomgroup. https://www.telkom.co.id/sites/about-telkom/id_ID/page/profil-dan-riwayat-singkat-22. [10 November 2021]

[13] Rencher, A. C. \& Schaalje G. B., 2008. Linier Models in Statistic Second Edition. New Jersey: Wiley and Sons

[14] Subagyo, P., 1986. Forecasting Konsep dan Aplikasi. Yogyakarta: BPFE Yogyakarta.

[15] Wei, W.W.S., 2006. Time Series Analysis Unvariate and Multivariate Methods: Second Edition. New York: Pearson Education Inc.

[16] Zhang, G.P., 2003. Time series forecasting using a hybrid ARIMA and neural network model. Neurocomputing, Vol. 50, 159-173. 